\title{
Development of an SPR imaging biosensor for determination of cathepsin $G$ in saliva and white blood cells
}

\author{
Ewa Gorodkiewicz • Elżbieta Regulska • \\ Kazimierz Wojtulewski
}

Received: 2 December 2010 / Accepted: 8 February 2011 /Published online: 2 March 2011

(C) The Author(s) 2011. This article is published with open access at Springerlink.com

\begin{abstract}
Cathepsin G (CatG) is an endopeptidase that is associated with the early immune response. The synthetic compound cathepsin G inhibitor I (CGI-I) was tested for its ability to inhibit the activity of CatG via a new surface plasmon resonance imaging assay. CGI-I was immobilized on the gold surface of an SPR sensor that was first modified with 1-octadecanethiol. A concentration of CGI-I equal to $4.0 \mu \mathrm{g} \cdot \mathrm{mL}-1$ and a $\mathrm{pH}$ of 8.0 were found to give the best results. The dynamic response of the sensor ranges from 0.25 to $1.5 \mathrm{ng} \cdot \mathrm{mL}-1$, and the detection limit is $0.12 \mathrm{ng} \cdot \mathrm{mL}-1$. The sensor was applied to detect CatG in human saliva and white blood cells.
\end{abstract}

Keywords Biosensor - Cathepsin G · Cathepsin G inhibitor I · Surface plasmon resonance imaging

\section{Introduction}

Cathepsin G (EC 3.4.21.20) is one of the serine endopeptidases. It is stored in the azurophilic granules of neutrophilic

E. Gorodkiewicz $(\bowtie) \cdot$ K. Wojtulewski

Department of Electrochemistry, Institute of Chemistry, University of Bialystok,

A1.J.Pilsudskiego11/4,

PL-15-443 Bialystok, Poland

e-mail: ewka@uwb.edu.pl

E. Regulska

Department of General and Inorganic Chemistry,

Institute of Chemistry, University of Bialystok,

Hurtowa 1,

PL-15-399 Bialystok, Poland polymorphonuclear leukocytes, but is also present in monocytes and mast cells [1].

The physiological role of cathepsin $\mathrm{G}(\mathrm{CatG})$ in the living organism is mainly associated with early immune response, but its biological activity is not limited to this. CatG is involved in several physiological processes such as tissue degradation, platelet activation, monocyte and neutrophil chemotaxis, proteolysis of blood coagulation factors, and generation of angiotensin II. It also displays a broad spectrum of antiviral, antibacterial, and antifungal activities. The potent antibacterial activity of CatG is independent of its proteolytic activity. The antibacterial action of CatG is thought to contribute significantly to the nonoxidative antibacterial capacity of neutrophils [2-5].

Together with similarly localized human neutrophil elastase and proteinase 3, CatG represents a major class of enzymes utilized in the phagocythic pathways to degrade foreign organisms and dead tissues during inflammatory reactions. Neutrophils play a key role in host defense by migrating to sites of infection, where they phagocytose invading microorganisms. After a neutrophil encloses a microbe, the resulting phagosome fuses with granules containing microbicidal and digestive enzymes to form a phagolysosome. The azurophilic granules of neutrophils are rich in serine proteases, including CatG and neutrophil elastase, which play critical roles in killing bacteria. Neutrophils are also known to invade many tumor tissues and influence tumor development, whereas CatG in neutrophils has a role in the dissemination of tumor aggregates from orimary tumor sites later to be secreted out by infiltrated neutrophils [5-7].

Activity of CatG, as well as other serine endopeptidases, is controlled by one or more members of the serine proteinase inhibitor (serpin) protein superfamily. However, an imbalance between proteases and serpins is implicated in 
tissue damage during inflammation [6]. In ischaemic diseases the impaired balance between $\mathrm{CatG}$ and its physiological inhibitors leads to tissue destruction and platelet aggregation. Inhibitors of $\mathrm{CatG}$ are thus suitable for the treatment of inflammatory diseases and procoagulant conditions [8]. Serpins can fail quantitatively or qualitatively in down-regulation due to genetic or acquired deficiencies. This results in the disturbed digestion of extracellular proteins that could contribute to the development of connective tissue diseases, such as emphysema, rheumatoid arthritis and perionditis [6].

Information concerning the determination of CatG is very scanty. Activities of CatG were determined using highly sensitive Abz-peptidyl-EDDnp fluorescence resonance energy transfer [9]. Elastase, proteinase 3 and $\mathrm{CatG}$ activities at the surface of human neutrophils were determined with fluorescence resonance energy transfer, and micellar electrokinetic chromatography (MEKC). MEKC was also use for simultaneous determination of Pseudomonas aeruginosa elastase, human leukocyte elastase and CatG activities [10]. In most cases activities of $\mathrm{CatG}$ are determined jointly by modification of the Barrett's method [11], or using indirect immunofluorescence and fixed granulocyte ELISA [12].

The aim of this work was to develop an SPRI biosensor for the highly selective determination of CatG and to demonstrate the sensor applicability for the determination of the enzyme in different human body fluids. Highly selective interaction of $\mathrm{CatG}$ with immobilized cathepsin $\mathrm{G}$ inhibitor I (CGI-I) was utilised for sensor development. CGI-I, a potent, selective, reversible, competitive, non-peptide inhibitor of CatG $\left(\mathrm{IC}_{50}=53 \mathrm{nmol} \cdot \mathrm{L}-1\right.$ and $\left.\mathrm{K}_{\mathrm{i}}=63 \mathrm{nmol} \cdot \mathrm{L}-1\right)$ is a 620.6 Da-molecular compound. CGI-I weakly inhibits chymotrypsin $\left(\mathrm{K}_{\mathrm{i}}=1.5 \mu \mathrm{mol} \cdot \mathrm{L}-1\right)$ and poorly inhibits thrombin, factor $\mathrm{Xa}$, factor IXa, plasmin, rypsin, tryptase, proteinase 3 , and human leukocyte elastase $\left(\mathrm{IC}_{50}>100 \mu \mathrm{mol} \cdot \mathrm{L}-1\right)$ [13]. The strategy for designing the sensor involved the immobilization of thiol (1-octadecanethiol) on a gold surface, and then the immobilization of CGI-I using hydrophobic interactions.

The Surface Plasmon Resonance Imaging (SPRI) technique is a promising tool for the development of sensitive sensors for biologically active species. It was applied for the determination of $\beta$-2-microglobulin, mucin, novel protein immunostimulating factor, microRNAs, DNA, cystatin $\mathrm{C}$, cysteine cathepsins, cathepsin D and E, papain [14-22].

\section{Experimental}

\section{Reagents}

CatG from human sputum, 1-octadecanethiol (ODM), Tween 20, (ALDRICH, Steinheim, Germany, www.sigmaaldrich. com), cathepsin B (CatB) from human liver, CGI-I (CALBIOCHEM, Merck group, Merck Sp. z.o.o., Warsaw, Poland, www.merck-chemicals.pl) were used, as well as absolute ethanol, acetic acid, sodium hydroxide, sodium chloride, sodium carbonate, sodium phosphate, potassium phosphate, sodium acetate, potassium chloride, magnesium chloride (all POCh, Gliwice, Poland, www.poch.com.pl), HBS-ES solution $\mathrm{pH}=7.4(0.01 \mathrm{M}$ HEPES, $0.15 \mathrm{~mol} \cdot \mathrm{L}-1$ sodium chloride, $0.005 \%$ Tween $20,3 \mathrm{mmol} \cdot \mathrm{L}-1$ EDTA), acetic buffer $\mathrm{pH}=3.79-5.57$, phosphate buffer $\mathrm{pH}=7.17$ 8.04, carbonate buffer $\mathrm{pH}=8.50-9.86$ (all BIOMED, Lublin, Poland, www.biomed.lublin.pl), photopolymer ELPEMER SD 2054, hydrophobic protective paint SD 2368 UV SG-DG (PETERS, Kempen, Germany, www.peters.de) were used as received. Aqueous solutions were prepared with milliQ water (Simplicity ${ }^{\circledR}$ MILLIPORE). Whole citrated blood was provided by the Haematology Clinic of the Medical University in Bialystok, Poland and saliva samples by the volunteers. All samples were provided after obtaining the requisite consent of the Bioethical Commission.

\section{Chip preparation}

Gold chips were manufactured as described in a previous paper [24]. The gold surface of the chip was covered with photopolymer and hydrophobic paint as described in a previous paper [23]. $9 \times 12$ free gold surfaces were obtained. Using this chip, nine different solutions can be simultaneously measured without mixing the tested solutions. Twelve single SPRI measurements can be performed from one solution.

\section{SPRI measurements}

SPRI measurements for protein array were performed as described in the previous papers [21-23]. A schematic diagram of the apparatus is given in Fig. 1. The SPRI set-up consists of HeNe laser (JDS Uniphase, Edmund Industrial Optics, USA), two glass lenses L1 $(f=3 \mathrm{~mm})$ and L2 $(f=$ $300 \mathrm{~mm}$ ), two polarizers (P1 and P2), mirror, prism and a CCD camera.

The chip consists of 9 detection areas, each containing an array of 12 spots. Spots are separated with photopolymer while detection areas are separated by hydrophobic paint. The picture of the chip is shown in Fig. 2a, while the image of the chip obtained by the CCD camera is shown in Fig. 2b.

Briefly, the measurements were performed at a fixed angle of incident light and reflectivity was simultaneously measured across an entire chip surface. The contrast values obtained for all pixels across a particular sample single spot were integrated. Thus the SPRI signal was integrated over the single spot area. Background correction was applied. 
Fig. 1 Scheme of SPRI set-up

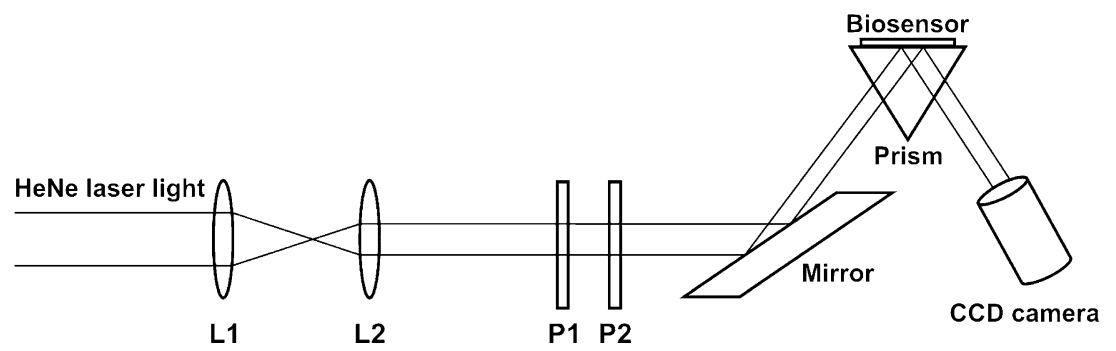

NIH Image J version 1.42 software was used to evaluate the SPRI images in $2 \mathrm{D}$ form. The signal was measured twice on the basis of registered images, after immobilisation of CGI-I and then after interaction with CatG. The SPRI signal, which is proportional to coupled biomolecules, was obtained from subtraction between the signal before and after interaction with a biomolecule for each spot separately.

\section{CGI-I immobilization}

Chips were rinsed with ethanol and water and dried under a stream of nitrogen. They were then immersed in $10 \mathrm{~mL}$ of $2.7 \mathrm{mmol} \cdot \mathrm{L}-1$ ODM ethanolic solutions for at least $24 \mathrm{~h}$. The chips were further rinsed with ethanol and water and dried under a stream of nitrogen. CGI-I solution $(3 \mu \mathrm{L}$ of CGI-I solution for each array of 12 spots) was placed on the thiol-modified surface and incubated at room temperature for $24 \mathrm{~h} \mathrm{[23].}$

\section{Preparation of the standard curve}

The response of the analytical SPRI signal for CatG concentration was measured within a concentration range between 0.25 and $2.5 \mathrm{ng} \cdot \mathrm{mL}-1$. The chip surface was covered by a monolayer of ODM and a layer of immobilized CGI-I $(4.0 \mu \mathrm{g} \cdot \mathrm{mL}-1)$. Experiments were performed at $\mathrm{pH}=8.0$. The interaction time was $10 \mathrm{~min}$.
Preparation of biological samples

White blood cells

$2 \mathrm{~mL}$ of whole blood was centrifuged over $15 \mathrm{~min}$ at $1,000 \times \mathrm{g}$. As a result, plasma was separated and white blood cells were collected. The solution of white blood cells was diluted two-fold with a buffer of $\mathrm{pH}=8.0$ and transferred onto the sensor surface for $10 \mathrm{~min}$. The volume of the sample applied on each detection area was $3 \mu \mathrm{L}$. The surface of the biosensor was then washed six times with the HBS-ES buffer. The SPRI measurement was performed. Concentration was evaluated using a calibration curve.

\section{Saliva}

$3 \mathrm{~mL}$ of saliva (in fasting state) was centrifuged over $15 \mathrm{~min}$ at $100 \times \mathrm{g}$ and a supernatant was separated. Finally, the sample was filtered three times through a paper filter of medium density. The prepared saliva was diluted two-fold with a buffer of $\mathrm{pH}=8.0$ and transferred onto the sensor surface for $10 \mathrm{~min}$. The volume of sample applied on each detection area was $3 \mu \mathrm{L}$. The surface of the biosensor was then washed six times with the HBS-ES buffer. The SPRI measurement was performed. Concentration was evaluated using a calibration curve.
Fig. 2 a Picture of chip (A-photopolymer, B-free gold surface, C-hydrophobic paint), b Image of chip obtained by CCD camera
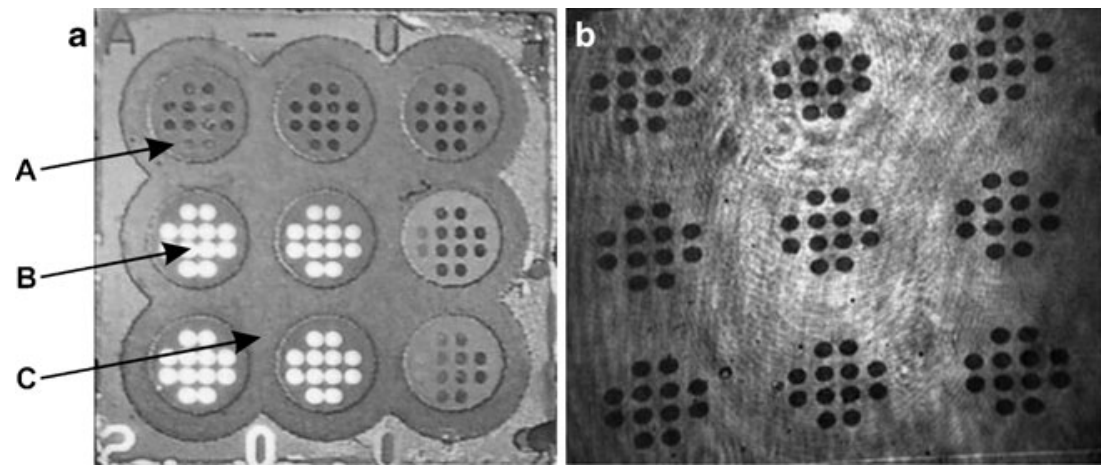


\section{Results and discussion}

Influence of CGI-I concentration on the analytical signal of $\mathrm{CatG}$

The purpose of this investigation was to find the best conditions for CatG determination. The investigation was performed within a CGI-I concentration range of 0.25 to $6.0 \mu \mathrm{g} \cdot \mathrm{mL}-1$ at constant CatG concentration $(1.0 \mathrm{ng} \cdot \mathrm{mL}-1)$. A series of 9 CGI-I solutions of increasing concentration were measured $(0.25,0.75,1.50,2.25,3.00,3.75,4.50$, $5,25$ and $6.00 \mu \mathrm{g} \cdot \mathrm{mL}-1)$. These solutions were transferred onto different points of the surface of a chip, which had been previously modified with ODM. CGI-I was immobilised during this treatment. The chip was then treated with the CatG solution $(1.0 \mathrm{ng} \cdot \mathrm{mL}-1)$ for $10 \mathrm{~min}$, rinsed with water and dried, and the SPRI measurement was performed. The results are given in Fig. 3 .

The obtained curve is a Langmuir isotherm type, with the plateau of the signal for CGI-I concentration above $3.00 \mu \mathrm{g} \cdot \mathrm{mL}-1$. A concentration of CGI-I equal to $4.00 \mu \mathrm{g} \cdot \mathrm{mL}-1$ was selected as optimal for further investigation.

Influence of solution $\mathrm{pH}$ on the interaction process

The influence of $\mathrm{pH}$ of CatG solution on the SPRI signal was studied for 13 different $\mathrm{pH}$ values (within the range 3.0-10.0) under conditions of constant concentrations of CatG (1 ng.mL-1) and CGI-I (4.0 $\mu \mathrm{g} \cdot \mathrm{mL}-1)$. Solutions of CGI-I were transferred onto different points of a chip which had been previously modified with ODM. In this manner CGI-I was immobilised onto the chip surface. The chip was then treated with CatG solutions $(1 \mathrm{ng} \cdot \mathrm{mL}-1)$ with different $\mathrm{pH}$ values, for $10 \mathrm{~min}$. The results are shown in Fig. 4.

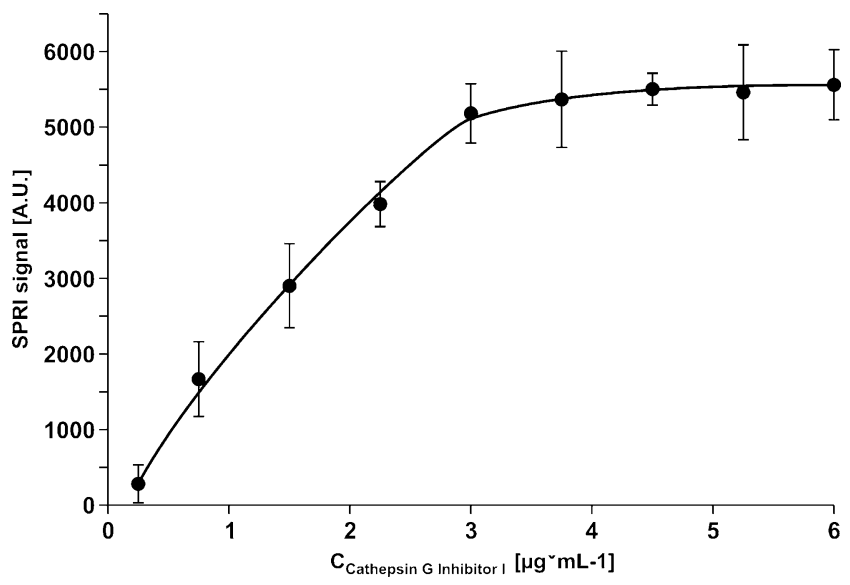

Fig. 3 Dependence of SPRI signal (Arbitrary Units) of CGI-I-CatG complex on CGI-I concentration. CatG concentration: $1.0 \mathrm{ng} \cdot \mathrm{mL}-1$. Initial $\mathrm{pH}$ of $\mathrm{CatG}$ solution: 8.0

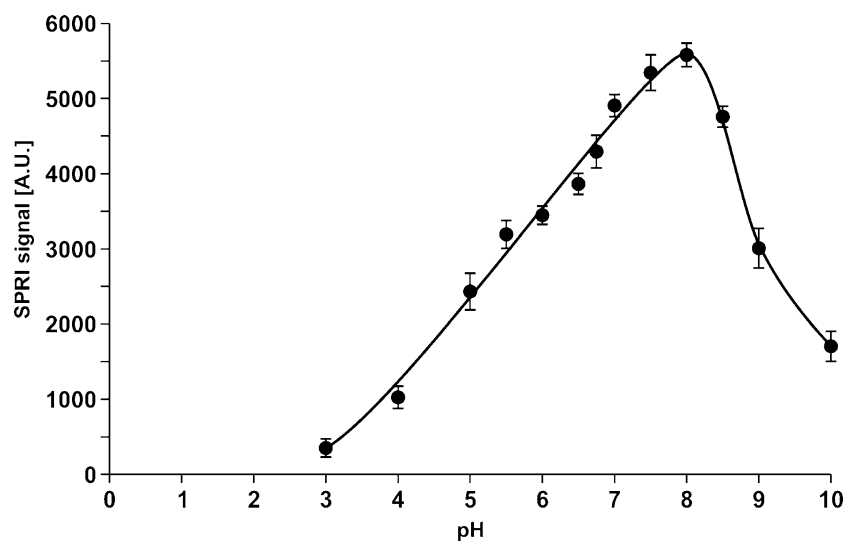

Fig. 4 Dependence of SPRI signal (Arbitrary Units) of CGI-I-CatG complex on $\mathrm{pH}$. Initial CGI-I concentration: $4.0 \mu \mathrm{g} \cdot \mathrm{mL}-1$. Initial CatG concentration: $1 \mathrm{ng} \cdot \mathrm{mL}-1$

As is apparent from the diagram, the maximum of the SPRI signal for CGI-I-CatG complex is for $\mathrm{pH}=8.0$. The value of $\mathrm{pH}=8.0$ was selected as optimal for further investigation.

Analytical response of the sensor to CatG concentration. Calibration curves

The response of the analytical SPRI signal for CatG concentration was measured within a range of concentration of between 0.25 and $2.5 \mathrm{ng} \cdot \mathrm{mL}-1$. The chip surface was covered by a monolayer of ODM and a layer of immobilized CGI-I $(4.0 \mu \mathrm{g} \cdot \mathrm{mL}-1)$. The experiments were performed at $\mathrm{pH}=8.0$. The time of interaction was $10 \mathrm{~min}$. The obtained calibration curve is shown in Fig. 5 .

The calibration curves represent a Langmuir isotherm type with the dynamic response range between 0.25 and

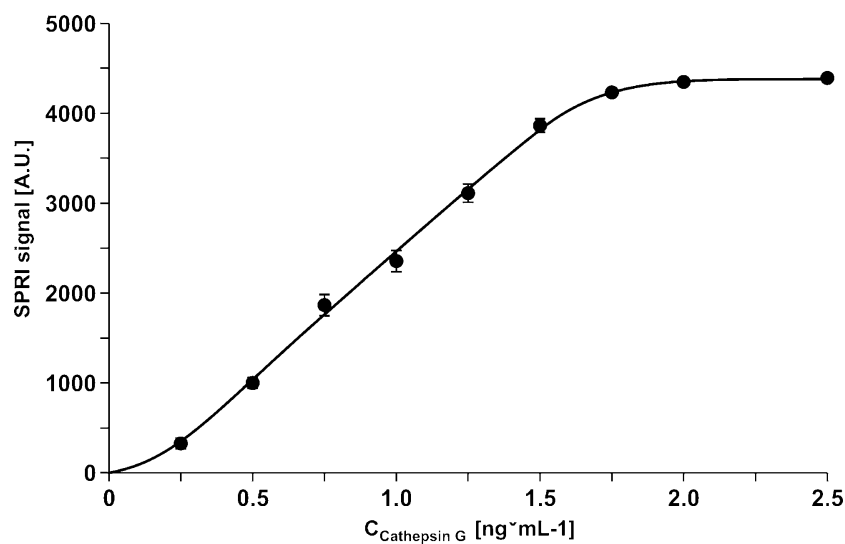

Fig. 5 Dependence of SPRI signal (Arbitrary Units) on CatG concentration. Initial $\mathrm{pH}$ value of CatG solution: 8.0 
Table 1 Influence of $\mathrm{CatB}$ on results of $\mathrm{CatG}$ determination. Concentration of CatG: $1 \mathrm{ng} \cdot \mathrm{mL}-1$

\begin{tabular}{llll}
\hline $\begin{array}{l}\text { CatG : } \\
\text { CatB }\end{array}$ & $\begin{array}{l}\text { Added CatG } \\
{[\mathrm{ng} \cdot \mathrm{mL}-1]}\end{array}$ & $\begin{array}{l}\text { Found CatG } \\
{[\mathrm{ng} \bullet \mathrm{mL}-1]}\end{array}$ & $\begin{array}{l}\text { Recovery } \\
{[\%]}\end{array}$ \\
\hline $1: 1$ & 1.00 & $1.06 \pm 0.02$ & 106 \\
$1: 10$ & 1.00 & $1.10 \pm 0.11$ & 110 \\
$1: 100$ & 1.00 & $1.01 \pm 0.09$ & 101 \\
$1: 1000$ & 1.00 & $1.02 \pm 0.05$ & 102 \\
\hline
\end{tabular}

$1.5 \mathrm{ng} \cdot \mathrm{mL}-1(0.01-0.06 \mathrm{nmol} \cdot \mathrm{L}-1)$. This section is useful for analytical purposes. The plateau of the curve corresponds to saturation of active points of the sensor. The detection limit calculated on the 3 S.D. basis is equal to $0.12 \mathrm{ng} \cdot \mathrm{mL}-1$.

\section{Selectivity of the CGI-I-CatG interaction}

In order to be sure that the interaction between CGI-I and $\mathrm{CatG}$ is selective and the sensor does not react with the other enzymes of the cathepsin family, the chip containing immobilised CGI-I was treated with mixtures of $\mathrm{CatG}$ and CatB. Various excesses of CatB within the range from 1:1 to $1: 1000$ were examined. Results are shown in Table 1.

The results show no influence of CatB on the results of determination of CatG even at a 1000-fold excess. Thus sensor high selectivity was confirmed.

The problem of the development of a specific sensor for CatG requires a specific inhibitor for this cathepsin. There is only one commercially available inhibitor of CatG, which was used in this research. However, there are reports about developments of new potent inhibitors of CatG [2]. Construction of a biosensor with the use of one of them is the subsequent goal of the authors.

Precision of the method for CatG determination

Precision of the method was tested under optimal conditions, i.e. $\mathrm{pH}=8.0$ and CGI-I concentration at the chip preparation stage equal to $4.0 \mu \mathrm{g} \cdot \mathrm{mL}-1$. The precision of CatG determination was tested for the concentration of this enzyme equal to $1.00 \mathrm{ng} \cdot \mathrm{mL}-1$. The results are shown in Table 2.
Standard deviation and the confidence limit, assuming that the confidence level equals $95 \%$, are relatively high. This indicates that the biosensor has a relatively low precision. However, the effect of relatively poor precision is compensated by large number of repetitions, because the sensor is an array of 12 analyzed spots. Therefore, recoveries of spikes are good.

Recovery of the method was checked by addition of spikes of CatG into a real samples of white blood cells. The results are given in Table 3.

Atomic force microscopy measurements

Atomic Force Microscopy (AMF) enables observation of the surface of the biosensor. AFM was used to confirm the creation of each layer: thiol (ODM), inhibitor (CGI-I) and the enzyme (CatG). Pictures were taken of bare gold (Fig. 6a), ODM (Fig. 6b), CGI-I (Fig. 6c) and CatG (Fig. 6d). The presented AFM pictures confirm that the described stages of the creation of each layer on the biosensor surface have really taken place. This may be concluded on the basis of the creation of different structures after each stage.

CatG determination in real samples

\section{White blood cells samples}

Samples of white blood cells from 9 patients suffering from leukemia were analysed for $\mathrm{CatG}$ determination using the sensor. The results for patients are given in Table 4. Concentration of CatG in white blood cells of donors was below the detection limit, so it could not be estimated.

Obtained results for CatG in white blood cells of patients suffering from leukemia are within the range of 2.37 to $234.1410^{-5} \mathrm{ng} \cdot 10^{3}$ white blood cells. Due to different type and stage of leukemia, these concentrations varied within a wide range.

\section{Saliva samples}

CatG was determined in 6 samples of saliva in order to demonstrate the sensor's applicability to this purpose. The results are shown in Table 5.

The range of CatG concentration in the saliva of donors aged 19-24 is between 1.25 and $2.17 \mathrm{ng} \cdot \mathrm{mL}-1$, while

Table 2 Precision of concentration measurement of CatG

\begin{tabular}{lllllll}
\hline Number of measurements & $\begin{array}{l}\text { Added } \\
{[\mathrm{ng} \bullet \mathrm{mL}-1]}\end{array}$ & $\begin{array}{l}\text { Found } \\
{[\mathrm{ng} \bullet \mathrm{mL}-1]}\end{array}$ & Recovery [\%] & $\begin{array}{l}\text { S.D. } \\
{[\mathrm{ng} \bullet \mathrm{mL}-1]}\end{array}$ & $\begin{array}{l}\text { Confidence (confidence limit, } \\
95 \%)[\mathrm{ng} \bullet \mathrm{mL}-1]\end{array}$ \\
\hline $\mathrm{CatG}$ & 24 & 1.00 & 1.02 & 102 & 0.39 & 0.15 \\
\hline
\end{tabular}


Table 3 Recoveries of spike CatG in white blood cells in comparison to the addition of standard

\begin{tabular}{rcccr}
\hline & $\begin{array}{l}\text { CatG concentration } \\
\text { without spike [ng・mL-1 }\end{array}$ & $\begin{array}{l}\text { Added CatG } \\
{[\mathrm{ng} \bullet \mathrm{mL}-1]}\end{array}$ & $\begin{array}{l}\text { Found CatG } \\
{[\mathrm{ng} \bullet \mathrm{mL}-1]}\end{array}$ & \multicolumn{1}{l}{$\begin{array}{l}\text { Recovery } \\
{[\%]}\end{array}$} \\
\hline 1 & $0.81 \pm 0.01$ & 0.50 & $1.31 \pm 0.03$ & 98.11 \\
2 & $0.98 \pm 0.03$ & 0.50 & $1.48 \pm 0.04$ & 98.97 \\
3 & $0.76 \pm 0.05$ & 0.50 & $1.27 \pm 0.05$ & 101.05 \\
4 & $0.95 \pm 0.05$ & 0.50 & $1.46 \pm 0.04$ & 98.56 \\
5 & $0.88 \pm 0.04$ & 0.50 & $1.38 \pm 0.05$ & 99.04 \\
6 & $0.91 \pm 0.03$ & 0.50 & $1.41 \pm 0.04$ & 100.72 \\
\hline
\end{tabular}

donors over 75 present concentration between 3.18 and $3.51 \mathrm{ng} \cdot \mathrm{mL}-1$. The changes of CatG activity in saliva can play an important role in the pathobiochemistry and diagnostics of salivary gland, gingiva, and oral mucosa diseases. It is worth stressing that an elevated CatG concentration in saliva can be a symptom of oral cavity diseases [25].

\section{Conclusions}

A selective SPRI array biosensor for the determination of CatG has been developed. The sensor works on the basis of a
Table 4 Concentration of CatG in white blood cells of patients suffering from leukemia

\begin{tabular}{llr}
\hline Patient number & Type of leukaemia & $\begin{array}{l}\text { Mass of CatG in white } \\
\text { blood cells } 10^{5}\left[\mathrm{ng} \cdot 10^{3}\right. \\
\text { white blood cells] }\end{array}$ \\
\hline 1 & AML & $31.12 \pm 1.11$ \\
2 & CLL & $13.63 \pm 0.55$ \\
3 & CML & $2.37 \pm 0.11$ \\
4 & CLL & $21.02 \pm 2.18$ \\
5 & BL & $131.25 \pm 6.86$ \\
6 & CLL & $234.14 \pm 3.01$ \\
7 & CLL & $14.07 \pm 0.18$ \\
8 & CLL & $122.27 \pm 3.02$ \\
9 & CLL & $82.86 \pm 3.56$ \\
\hline
\end{tabular}

CLL chronic lymphocytic leukaemia; CML chronic myelogenous leukaemia; $A M L$ acute myelogenous leukaemia; $B L$ Burkitt lymphoma

highly selective reaction between immobilised CGI-I and $\mathrm{CatG}$ in solution. Under optimised conditions, the sensor exhibits selectivity to cathepsin G, and the precision and accuracy is well suited to enzyme determination. The sensor can be used for the determination of CatG in white blood cells and saliva.
Fig. 6 AFM pictures of bare gold (a), 1-octadecanethiol (b), CGI-I (c) and CatG (d)
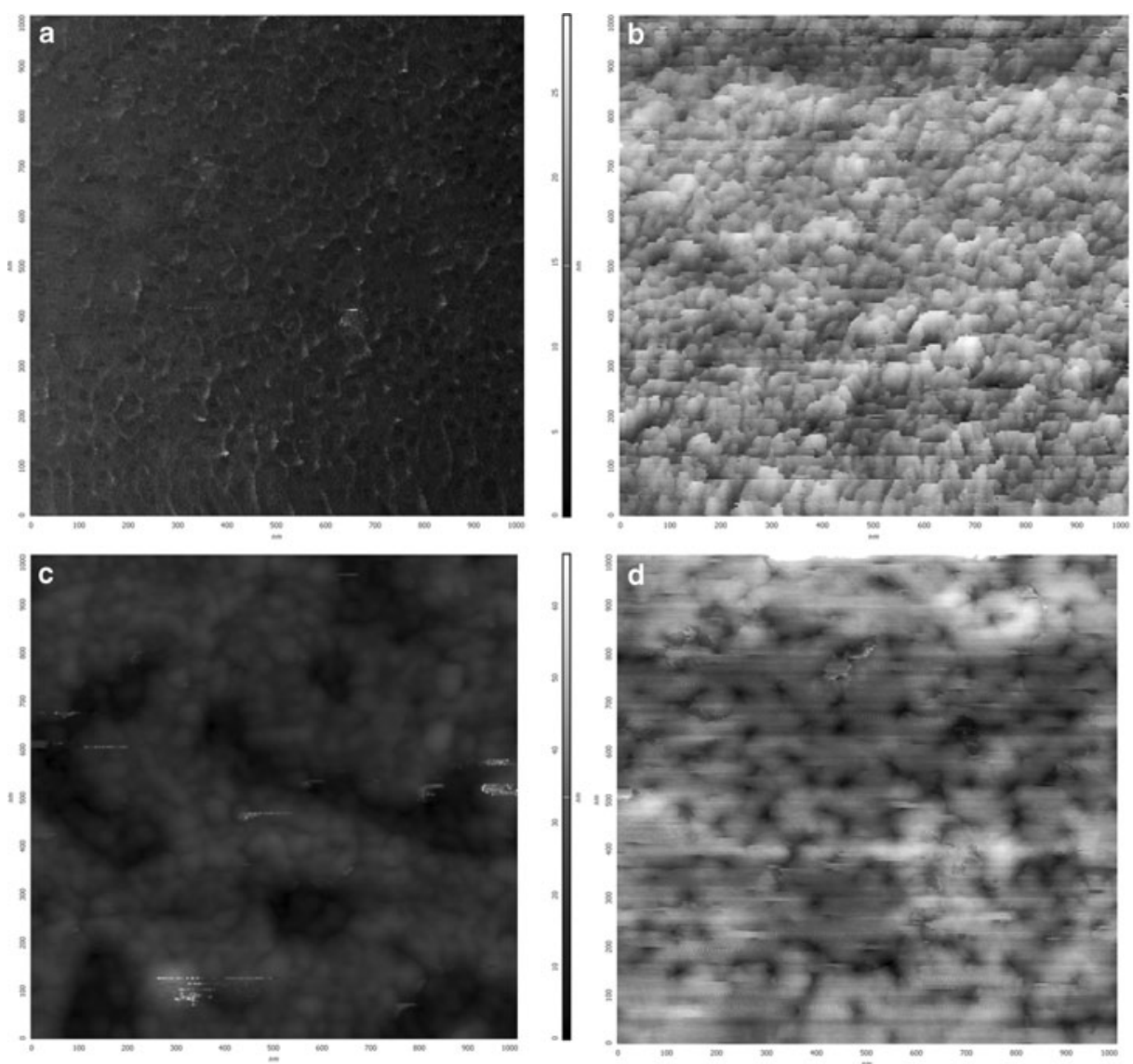
Table 5 Concentration of CatG in saliva of donors with an age range of 19-24 and over the age of 75

\begin{tabular}{lcl}
\hline Sample number & \multicolumn{2}{l}{ CatG concentration $[\mathrm{ng} / \mathrm{ml}]$} \\
\cline { 2 - 3 } & $\begin{array}{l}\text { Donors with an age } \\
\text { range of 19-24 }\end{array}$ & $\begin{array}{l}\text { Donors over the } \\
\text { age of } 75\end{array}$ \\
\hline 1 & $1.96 \pm 0.01$ & $3.51 \pm 0.03$ \\
2 & $2.17 \pm 0.04$ & $3.38 \pm 0.04$ \\
3 & $1.25 \pm 0.39$ & $3.27 \pm 0.07$ \\
4 & $1.82 \pm 0.03$ & $3.49 \pm 0.19$ \\
5 & $1.88 \pm 0.36$ & $3.18 \pm 0.01$ \\
6 & $1.37 \pm 0.31$ & $3.40 \pm 0.03$
\end{tabular}

Acknowledgements Doctor J. Svieklo is greatly thanked for offering invaluable help with Atomic Force Microscope. Prof. J. Kloczko and dr J. Piszcz from Hematology Clinic of Medical University of Bialystok are greatly thanked for making available to us the blood samples of leukaemia patients. Very fruitful consultations with Professor Zenon Lukaszewski from Poznan University of Technology are greatly appreciated. Professor Zbigniew Artur Figaszewski from the University in Bialystok is thanked for creating a stimulating climate for our research.

Open Access This article is distributed under the terms of the Creative Commons Attribution Noncommercial License which permits any noncommercial use, distribution, and reproduction in any medium, provided the original author(s) and source are credited.

\section{References}

1. Polanowska J, Krokoszyńska I, Czapińska H, Watorek W, Dadlez M, Otlewski J (1998) Specificity of human cathepsin G. Biochim Biophys Acta 1386:189-198

2. Sieńczyk M, Lesner A, Wysocka M, Łęgowska A, Pierusiewicz E, Rolka K, Oleksyszyn J (2008) New potent cathepsin G phosphonate inhibitors. Bioorg Med Chem 16:8863-8867

3. Lesner A, Wysocka M, Guzow K, Wiczk W, Legowska A, Rolka K (2008) Development of sensitive cathepsin G fluorogenic substrate using combinatorial chemistry methods. Anal Biochem 375:306-312

4. Gütschow M, Kuerschner L, Pietsch M, Ambrożak A, Neumann U, Günther R, Hofmann HJ (2002) Inhibition of cathepsin $G$ by 2-amino-3, 1-benzoxazin-4-ones: kinetic investigations and docking studies. Arch Biochem Biophys 402:180-191

5. Kudo T, Kigoshi H, Hagiwara T, Takino T, Yamazaki M, Yui S (2009) Cathepsin G, a neutrophil protease, induces compact cellcell adhesion in MCF-7 human breast cancer cells. Mediat Inflamm 2009:1-11

6. Martins FT, Assis DM, Santos MH, Camps I, Veloso MP, Juliano MA, Alves LC, Doriguetto AC (2009) Natural polyprenylated benzophenones inhibiting cysteine and serine proteases. Eur J Med Chem 44:1230-1239

7. Shao B, Belaaouaj A, Verlinde CLMJ, Fu X, Heinecke JW (2005) Methionine sulfoxide and proteolytic cleavage contribute to the inactivation of cathepsin $\mathrm{G}$ by hypochlorous acid: an oxidative mechanism for regulation of serine proteinases by myeloperoxidase. J Biol Chem 280:29311-29321
8. Gatto B, Vianini E, Lucatello L, Sissi C, Moltrasio D, Pescador R, Porta R, Palumbo M (2008) Effective DNA inhibitors of cathepsin $\mathrm{G}$ by in vitro selection. Int J Mol Sci 9:1008-1023

9. Korkmaz B, Attucci S, Juliano MA, Kalupov T, Jourdan ML, Juliano L, Gauthier F (2008) Measuring elastase, proteinase 3 and cathepsin $G$ activities at the surface of human neutrophils with fluorescence resonance energy transfer substrates. Nat Protoc 3:991-1000

10. Viglio S, Luisetti M, Zanaboni G, Döring G, Worlitzsch D, Cetta G, Iadarola P (1999) Simultaneous determination of pseudomonas aeruginosa elastase, human leukocyte elastase and cathepsin G activities by micellar electrokinetic chromatography. J Chromatogr A 846:125-134

11. Barrett AJ (1981) Cathepsin G. In: Colowick SP, Kaplan NO (eds) Methods in enzymology, volume 80 . Academic, New York, pp 561-565

12. Halbwachs-Mecarelli L, Nusbaum P, Noël H, Reumaux D, Erlinger S, Grünfeld JP, Lesavre P (1992) Antineutrophil cytoplasmic antibodies (ANCA) directed against cathepsin G in ulcerative colitis, Crohn's disease and primary sclerosing cholangitis. Clin Exp Immunol 90:79-84

13. Greco MN, Hawkins MJ, Powell ET, Almond HR, Corcoran TW Jr, de Garavilla L, Kauffman JA, Recacha R, Chattopadhyay D, Andrade-Gordon P, Maryanoff BE (2002) Nonpeptide inhibitors of cathepsin G: optimization of a novel $\beta$-ketophosphonic acid lead by structure-based drug design. J Am Chem Soc 124:3810-3811

14. Fernández-González A, Rychlowska J, Badía R, Salzer R (2007) SPR imaging as a tool for detecting mucin-anti-mucin interaction. Outline of the development of a sensor for near-patient testing for mucin. Microchim Acta 158:219-225

15. Chen H, Lee J, Jo WS, Jeong MH, Koh K (2010) Development of surface plasmon resonance immunosensor for the novel protein immunostimulating factor. Microchim Acta. doi:10.1007/s00604010-0476-0

16. Lee HJ, Yan Y, Marriott G, Corn RM (2005) Quantitative functional analysis of protein complexes on surfaces. J Physiol 563:61-71

17. Lee HJ, Nedelkov D, Corn RM (2006) Surface plasmon resonance imaging measurements of antibody arrays for the multiplexed detection of low molecular weight protein biomarkers. Anal Chem 78:6504-6510

18. Fang S, Lee J, Wark AW, Corn RM (2006) Attomole microarray detection of MicroRNAs by nanoparticle-amplified SPR imaging measurements of surface polyadenylation reactions. J Am Chem Soc 128:14044-14046

19. Gorodkiewicz E, Regulska E, Roszkowska-Jakimiec W (2010) Determination of the active form concentration of cathepsins D and B by SPRI biosensors. J Lab Diagn 46:107-109

20. Gorodkiewicz E, Regulska E (2010) SPR imaging biosensor for aspartyl cathepsins: sensor development and application for biological material. Protein Pept Lett 17:1148-1154

21. Gorodkiewicz E (2007) The surface plasmon resonance imaging sensor for papain based on immobilized cystatin. Protein Pept Lett $14: 443-445$

22. Gorodkiewicz E (2009) Surface plasmon resonance imaging sensor for cathepsin determination based on immobilized cystatin. Protein Pept Lett 16:1379-1385

23. Gorodkiewicz E, Fernández-González A, Akkoyun A, Salzer R (2005) Systematic evaluation of a surface plasmon resonance imaging biochip reader: study of gold surface modifications. Chem Anal (Warsaw) 50:103-116

24. Ozmeric N (2004) Advances in periodontal disease markers. Clin Chim Acta 343:1-16 